\title{
Kepastian Hukum Wilayah Jabatan Notaris Sebagai Pemegang Protokol Notaris Yang Berakhir Masa Jabatannya
}

\section{Putu Bellania Ariawan. ${ }^{1}$}

${ }^{1}$ Magister Kenotariatan Fakultas Hukum Universitas Udayana, E-mail: bella.aria21@gmail.com

\begin{tabular}{l}
\hline Info Artikel \\
\hline Keywords : \\
legal certainty, notary, \\
notary office area \\
\\
\\
Corresponding Author: \\
butu Bellania Ariawan, E-mail: \\
Della.aria21@gmail.com \\
10.24843/AC.2018.v03.i02.p09 \\
Kata kunci: \\
kepastian hukum, notaris, \\
wilayah jabatan notaris \\
\end{tabular}

\begin{abstract}
A notary is permitted to have a position in only one city / regency, but in relation to his office, the authority he has is in all provinces of the city / regency. In relation to the notary's office area, there is still legal uncertainty and obscurity in the legal norms contained in the provisions of Article 63 paragraph (4) of the UUJN and its implementing regulations, namely Article 7 and 8 of the Republic of Indonesia Law and Human Rights Minister's Regulation Number 27 of 2016 concerning Position Formation Notary and Determination of the Category of Regions related to the formation of the position area for the appointment of the first Notary who also acts as the recipient of the Notary protocol which ends his term. This research is a normative legal research, with a legislative approach, using primary and secondary legal materials that are carried out through literature review techniques, then analyzed using description and interpretation techniques. The results showed that, there was still a vague norm by not explaining whether the notary who was first appointed and at the same time appointed as the protocol holder of the notary who had ended his term of office could automatically enter the retired notary working area. When referring to Article 8 of the Regulation of the Minister of Law and Human Rights of the Republic of Indonesia Number 27 of 2016 concerning Formation of Notary Position and Determination of Regional Categories, then the notary who is first appointed can only be domiciled in the specified regional category.
\end{abstract}

\footnotetext{
Abstrak

Seorang notaris diperbolehkan untuk memiliki kedudukan hanya di satu wilayah kota/kabupaten saja, namun terkait dengan wilayah jabatannya kewenangan yang dimiliki adalah di seluruh wilayah propinsi dari wilayah kota/kabupaten kedudukannya. Berkaitan dengan wilayah jabatan notaris, masih terlihat adanya ketidakpastian hukum dan kekaburan norma hukum yang terdapat didalam ketentuan Pasal 63 ayat (4) UUJN serta peraturan pelaksananya yakni Pasal 7 dan 8 Peraturan Menteri Hukum Dan Hak Asasi Manusia Republik Indonesia Nomor 27 Tahun 2016 tentang Formasi Jabatan Notaris Dan Penentuan Kategori Daerah terkait dengan formasi wilayah jabatan
} 
pengangkatan Notaris pertama kali yang juga bertindak sebagai penerima protokol Notaris yang berakhir masa jabatannya. Penelitian ini adalah penelitian hukum normatif, dengan pendekatan perundang-undangan, menggunakan bahan hukum primer dan sekunder yang dilakukan melalui teknik telaah kepustakaan, kemudian dianalisis menggunakan teknik deskripsi dan interpretasi. Hasil penelitian menunjukkan bahwa, masih terdapat kekaburan norma dengan tidak dijelaskannya mengenai apakah notaris yang baru diangkat dan sekaligus ditunjuk sebagai pemegang protokol dari notaris yang telah berakhir masa kerjanya tersebut dapat dengan otomatis langsung masuk ke wilayah kerja notaris yang telah berakhir masa jabatannya tersebut. Apabila mengacu kepada Pasal 8 Peraturan Menteri Hukum Dan Hak Asasi Manusia Republik Indonesia Nomor 27 Tahun 2016 tentang Formasi Jabatan Notaris Dan Penentuan Kategori Daerah, maka seharusnya notaris yang pertama kali diangkat hanya dapat berkedudukan di kategori daerah yang telah ditentukan.

\section{Pendahuluan}

Keberadaan profesi notaris yang secara fungsional berperan dalam kehidupan masyarakat sampai saat ini tetap masih terasa disegani. Selain dianggap sebagai seorang pejabat, notaris biasanya juga dianggap sebagai seseorang yang dapat memberikan nasihat-nasihat dan saran-saran yang sangat dapat dijadikan acuan. Semua hal yang ditulisnya, dan juga yang ditetapkan atau dikonstatir merupakan halhal yang dianggap benar, dan seorang notaris dianggap sebagai pembuat dokumen yang dianggap memiliki kedudukan yang kuat didalam sebuah proses hukum. ${ }^{1}$ Sedangkan hukum itu sendiri diciptakan dalam rangka untuk mengatur manusia di dalam kehidupan bermasyarakat. Peran serta fungsi hukum hingga saat ini telah mengalami banyak perubahan. Berkembangnya peran dan fungsi hukum sejalan dengan perkembangan manusia, yang seiring berjalannya waktu membutuhkan adanya ketertiban, perlindungan, keadilan, dan kepastian hukum. Peran serta fungsi hukum yang mengatur dinamika kehidupan masyarakat ini juga mengatur segala jenis profesi dalam berbagai bidang kehidupan manusia.

Salah satu profesi yang termasuk adalah profesi notaris. Seorang notaris kerap juga dikatakan sebagai seorang pejabat yang mulia. Hal ini dikarenakan profesi itu sendiri sangatlah erat kaitannya dengan hubungan kemanusiaan. Produk dari notaris itu sendiri, yaitu akta yang dibuatnya, dapat menjadi sebuah dasar hukum dari status harta benda, serta hak dan kewajiban dari seseorang. Kesalahan-kesalahan dari akta yang dibuat oleh notaris itu mampu menciptakan keadaan dimana hak dan kewajiban

1Tan Thong Kie. (2011). Studi Notariat dan Serba-Serbi Praktek Notaris. Cetakan Kedua. Jakarta: PT. Ichtiar Baru van Hoeve. h. 444. 
dari seseorang akan dapat dicabut. ${ }^{2}$ Maka dari itu keberadaan peraturan-peraturan yang mengatur mengenai notaris itu sendiri sangat dibutuhkan, dengan harapan dapat memberikan kepastian dan perlindungan hukum yang baik, baik itu bagi notaris itu sendiri dan juga bagi masyarakat. Peraturan yang mengatur mengenai notaris itu sendiri yaitu Undang-Undang Nomor 2 Tahun 2014 tentang Perubahan atas UndangUndang Nomor 30 Tahun 2004 tentang Jabatan Notaris (UUJN).

Seorang notaris diperbolehkan untuk memiliki kedudukan hanya di satu wilayah kota/kabupaten saja, namun terkait dengan wilayah jabatannya kewenangan yang dimiliki adalah di seluruh wilayah propinsi dari wilayah kota/kabupaten kedudukannya. Selain daripada itu, seorang notaris juga hanya dapat untuk membuka satu buah kantor saja, tidak diperbolehkan untuk membuka kantor cabang maupun kantor perwakilan, serta tidak memiliki kewenangan untuk secara terus-menerus melaksanakan tugas jabatannya di luar dari wilayah kedudukan seorang notaris tersebut. Hal ini memiliki makna bahwa pembuatan akta semuanya diharapkan agar sedapat mungkin agar pelaksanaannya dilakukan dikantor notaris yang bersangkutan, keculai apabila memang ada akta-akta tertentu yang memang mangharuskan untuk dibuat diluar dari kantor notaris.

Pasal 21 UUJN menentukan yaitu seorang menteri memiliki kewenangan dalam hal penentuan formasi terkait jabatan seorang notaris didalam wilayah daerah yang termaksud didalam Pasal 18 ayat(1) dengan juga memperhitungkan pertimbangan usulan dari pihak organisasi notaris. Mengenai ketentuan pasal demi pasalnya, penjelasan dari Pasal 18 yaitu bahwa formasi adalah kebutuhan akan pengisian jabatan notaris. Menteri Hukum dan Hak Asasi Manusia dengan pertimbangan-pertimbangan usul dari organisasi notaris, dan berlandaskan atas formasi notaris, akan menempatkan setiap notaris pada daerah-daerah yang ditentukan. ${ }^{3}$ Mengenai pertimbangan ini sebagaimana ditentukan juga dalam Pasal 22 ayat (1) UUJN bahwa formasi jabatan notaris diatur secara spesifik tentang tata cara penempatannya yang ditentukan dengan mendasarkan pada kegiatan-kegiatan usaha, jumlah penduduk, dan juga berdasarkan pada jumlah rata-rata akta yang dibuat baik oleh notaris maupun yang dibuat di hadapan notaris dalam setiap bulannya. Peraturan menteri yang berfungsi sebagai peraturan pelaksana atas perintah ketentuan Pasal 22 ini adalah Peraturan Menteri Hukum Dan Hak Asasi Manusia Republik Indonesia Nomor 27 Tahun 2016 tentang Formasi Jabatan Notaris Dan Penentuan Kategori Daerah. Atas dasar peraturan di atas dapat disimpulkan bahwa mengenai penempatan formasi jabatan notaris mempunyai kriteria yang cukup ketat.

\footnotetext{
${ }^{2}$ Erwinsyahbana, T., \& Melinda, M. (2018). Kewenangan dan Tanggung Jawab Notaris Pengganti setelah Pelaksanaan Tugas dan Jabatan Berakhir. Lentera Hukum, 5(2), 305-321. h.30. ${ }^{3}$ Witasari, A. (2018). Mpd Bukan Advokat Para Notaris Berdasarkan Undang-undang No. 30 Tahun 2004 Tentang Jabatan Notaris. Jurnal Hukum, 28(2), 882-899. h.886.
} 
Berkaitan dengan bagaimana protokol notaris diserahkan, sebagaimana didalam Pasal 62 UUJN menentukan mengenai protokol notaris diserahkan salah satunya dapat dilaksanakan setelah berakhirnya masa jabatannya. Lebih lanjut, Pasal 63 ayat (4) menentukan bahwa pelaksanaan protokol notaris diserahkan yaitu dilaksanakan dari notaris pemilik protokol kemudian diserahkan kepada notaris lainnya yang telah ditetapkan dan ditunjuk oleh menteri berdasarkan pada usulan dari Majelis Pengawas Daerah. Berkaitan mengenai hal itu, maka notaris yang telah ditunjuk oleh Majelis Pengawas Daerah berkewajiban untuk menerima, menyimpan, dan meneruskan protokol milik notaris yang telah habis masa jabatannya. ${ }^{4}$ Namun ketentuan ini belum mengatur secara limitatif bagaimana dasar pertimbangan Majelis Pengawas Daerah untuk menunjuk notaris penerima protokol sebelum mengusulkannya kepada menteri.

Ketentuan-ketentuan di atas secara tegas mengatur mengenai formasi wilayah jabatan dan pengangkatan pertama kali notaris. Namun masih terlihat adanya ketidakpastian hukum dan kekaburan norma perihal formasi jabatan untuk notaris yang diangkat pertama kali serta bertindak juga sebagai penerima protokol sebagaimana ditunjuk atas usulan Majelis Pengawas Daerah. Belum ada aturan yang secara tegas mengatur mengenai notaris yang diangkat pertama kali sebagai pemegang protokol dari notaris yang berakhir masa kerjanya apakah dapat langsung menempati wilayah jabatan notaris pemberi protokol atau harus tetap mengikuti aturan dalam UUJN dan ketentuan Peraturan Menteri Hukum Dan Hak Asasi Manusia Republik Indonesia Nomor 27 Tahun 2016 tentang Formasi Jabatan Notaris Dan Penentuan Kategori Daerah. Hal ini dikarenakan apabila mengacu kepada Pasal 8 peraturan menteri ini, maka seharusnya notaris yang pertama kali diangkat tersebut tidak dapat langsung menempati wilayah jabatan notaris pemberi protokol, melainkan hanya dapat berkedudukan di wilayah yang telah ditetapkan oleh peraturan tersebut.

Beranjak dari kekaburan norma hukum yang terdapat didalam ketentuan Pasal 63 ayat (4) UUJN serta peraturan pelaksananya yakni Pasal 7 dan 8 Permenkumham diatas terkait dengan formasi wilayah jabatan pengangkatan Notaris pertama kali yang juga bertindak sebagai penerima protokol Notaris yang berakhir masa jabatannya yang ditunjuk Menteri atas usul Majelis Pengawas Daerah, menarik bagi penulis untuk mangangkat penelitian tentang "Kepastian Hukum Wilayah Jabatan Notaris Sebagai Pemegang Protokol Notaris Yang Berakhir Masa Jabatannya". Adapun permasalahan yang akan penulis bahas dalam penelitian ini yaitu bagaimanakah kepastian hukum formasi wilayah jabatan notaris yang diangkat pertama kali sebagai pemegang protokol notaris yang berakhir masa jabatannya, dan bagaimana pengaturan kedepan

\footnotetext{
${ }^{4}$ Andriana, R., \& Chalim, M. A. (2017). AKIBAT HUKUM BAGI NOTARIS YANG MENOLAK PROTOKOL DARI NOTARIS LAIN. Jurnal Akta, 4(2), 223-230. h. 226.
} 
formasi wilayah jabatan notaris yang diangkat pertama kali dan ditunjuk sebagai penerima protokol.

\section{Metode Penelitian}

Dalam rangka mengumpulkan dan menyusun bahan yang dipakai dalam rangka untuk menyusun dan membahas masalah didalam penelitian ini, penulis menggunakan metode penelitian hukum normatif, yaitu penelitian hukum yang dilakukan dengan berdasarkan atas adanya kabur norma maupun asas hukum. ${ }^{5}$ Kekaburan norma didalam penulisan ini yaitu dapat ditemukan didalam Pasal 63 ayat (4) UUJN serta peraturan pelaksananya yakni Pasal 7 dan 8 Peraturan Menteri Hukum Dan Hak Asasi Manusia Republik Indonesia Nomor 27 Tahun 2016 tentang Formasi Jabatan Notaris Dan Penentuan Kategori Daerah. Pendekatan yang digunakan dalam penelitian ini adalah pendekatan perundang-undangan, yaitu dengan cara mengkaji dan menganalisa peraturan perundang-undangan terkait dengan permasalahan untuk menemukan jawaban dari penelitian ini. Bahan hukum primer yang digunakan dalam penelitian ini terdiri dari beberapa ketentuan yaitu Undang-Undang No. 2 Tahun 2014 tentang Perubahan Atas Undang-Undang Nomor 30 Tahun 2004 tentang Jabatan Notaris, dan Peraturan Menteri Hukum Dan Hak Asasi Manusia Republik Indonesia Nomor 27 Tahun 2016 tentang Formasi Jabatan Notaris Dan Penentuan Kategori Daerah. Sedangkan bahan hukum sekunder yang digunakan adalah buku-buku hukum, jurnal-jurnal hukum, karya tulis hukum atau pandangan ahli hukum yang memiliki kaitan dengan penelitian ini. Berkaitan dengan teknik yang dipakai dalam rangka untuk mengumpulkan bahan hukum dalam tulisan ini, digunakan teknik studi pustaka dengan menggunakan sistem kartu, yang merupakan teknik dengan cara mengumpulkan semua bahan-bahan yang akan dibutuhkan lalu kemudian akan dibentuk catatan-catatan tentang hal-hal yang dirasa penting untuk penelitian yang akan dilakukan. ${ }^{6}$ Teknik deskripsi dan interpretasi digunakan dalam penelitian ini terkait dengan analisis mengenai bahan hukum. Teknik deskripsi ini menguraikan secara seutuhnya mengenai keadaan dan kondisi sebuah proposisi hukum. Sedangkan teknik interpretasi yaitu merupakan teknik yang menggunakan penafsiran ilmu hukum berupa penafsiran gramatikal, penafsiran historis, penafsiran sistematis, penafsiran teleology, penafsiran kontekstual, dan lainnya.

\section{Hasil Dan Pembahasan}

\subsection{Kepastian Hukum Wilayah Jabatan Notaris Sebagai Pemegang Protocol Notaris Yang Berakhir Masa Jabatannya}

Sebagaimana terlah tercantum didalam Pasal 22 ayat (1) UUJN yang menjadi dasar dari formasi jabatan notaris itu sendiri, menentukan bahwa mengenai formasi jabatan seorang notaris dapat ditentukan dengan berdasar pada kegiatan-kegiatan usaha, jumlah penduduk, dan juga berdasarkan pada jumlah rata-rata akta yang dibuat baik

5Jhony, Ibrahim. (2005). Teori \& Metodelogi Penelitian Hukum Normatif. Surabaya: Bayu Media. h. 284.

'Soerjono Soekanto dan Sri Mahmudji. (2003). Penelitian Hukum Normatif, Suatu Tinjauan Singkat. Jakarta: Raja Grafindo Persada. h.13. 
oleh notaris maupun yang dibuat di hadapan notaris dalam setiap bulannya. Kemudian lebih lanjut didalam ayat(2) ditentukan yaitu mengenai formasi jabatan tersebut adalah sebagai pedoman dalam rangka penentuan kategori daerah jabatan notaris.

Dengan penjelasan diatas dapat disimpulkan bahwa tercantum didalam ketentuan diatas mengenai formasi tersebut sesungguhnya adalah tidak menjadi bukan merupakan sebuah syarat. Formasi jabatan notaris disebutkan merupakan sebuah pedoman dalam rangka penentuan untuk kategori mengenai daerah jabatan seorang notaris. Digunakannya kata pedoman didalam ketentuan tersebut mengartikan yaitu mengenai formasi tersebut adalah merupakan sebuagh petunjuk, yang bisa saja diimplementasikan jika mempunyai nilai-nilai kebenaran. Dalam hal ini, sebuah pedoman dan petunjuk akan membutuhkan sebuah parameter yang jelas dan terukur. ${ }^{7}$

Peraturan Menteri Hukum Dan Hak Asasi Manusia Republik Indonesia Nomor 27 Tahun 2016 tentang Formasi Jabatan Notaris Dan Penentuan Kategori Daerah dalam kajian ini penulis melihat masih memiliki ketidakpastian hukum terkait dengan formasi jabatan Notaris pengangkatan pertama kali yang bertindak sebagai penerima protokol yang ditunjuk oleh Notaris yang berakhir masa kerjanya, apakah notaris tersebut akan dapat langsung menempati wilayah jabatan Notaris sebelumnya atau akan tetap mengikuti ketentuan tersebut diatas. Pasal 8 peraturan menteri tersebut secara lebih lanjut menentukan mengenai kategori daerah yaitu :

1.Kategori daerah A diperuntukan khusus perpindahan wilayah jabatan Notaris dari kategori daerah $\mathrm{B}$;

2.Kategori daerah B untuk perpindahan wilayah jabatan Notaris dari kategori daerah A dan kategori daerah $\mathrm{C}$;

3.Kategori daerah $C$ untuk perpindahan wilayah jabatan Notaris dari kategori daerah A, kategori daerah B, dan kategori daerah D;

4.Kategori daerah D untuk perpindahan wilayah jabatan Notaris dari seluruh kategori daerah dan pengangkatan Notaris.

Sebagaimana ditentukan didalam Pasal 1 butir 3 UUJN menentukan yaitu protocol notaris yang dimaksudkan merupakan dokumen-dokumen yang dikumpulkan yang adalah arsip negara yang wajib untuk dijaga dan di simpan oleh seorang notaris sebagaimana ditentukan didalam ketentuan perundangan. Dalam hal ini penyimpanan dokumen-dokumen sebagai protokol notaris dimaksud tetap dilaksanakan meskipun notaris tersebut sudah berakhir masa jabatannya maupun juga sudah meninggal. Dalam rangka pemeliharaan dokumen-dokumen protokol tersebut, maka protokol akan di serahkan dari notaris pemilik protokol kepada notaris lainnya yang ditunjuk sebagai notaris pemegang protokol. ${ }^{8}$

${ }^{7}$ Astiriani, R. G. (2015). Analisis Yuridis terhadap Putusan Mahkamah Konstitusi Nomor 5/puu-xii/2014 Terkait Ketentuan Formasi Jabatan Notaris dalam Uujn sebagai Syarat Pengangkatan Notaris. Kumpulan Jurnal Mahasiswa Fakultas Hukum. h.6.

8Purwanto, A. (2018). PERTANGGUNGJAWABAN AHLI WARIS NOTARIS DAN MPD TERHADAP PROTOKOL NOTARIS YANG MENINGGAL DUNIA. Jurnal Repertorium, 5(2). h. 3. 
Sesuai dengan yang tercantum didalam Pasal 62 UUJN bahwa terkait dengan penyerahan protokol notaris, salah satunya dapat dilakukan setelah notaris tersebut berakhir masa jabatannya. Lebih lanjut lagi, Pasal 63 ayat (4) UUJN menentukan bahwa apabila hal-hal termaksud didalam pasal 62 terjadi, maka dokumen-dokumen protokol tersebut penyerahannya akan dilaksanakan oleh notaris yang bersangkutan, diserahkan kepada notaris lainnya yang di tunjuk berdasarkan usulan dari MPD oleh menteri terkait. Ketentuan ini belum mengatur secara limitatif bagaimana dan apa yang menjadi dasar dari pertimbangan Majelis Pengawas Daerah dalam rangka untuk menunjuk notaris penerima protokol sebelum mengusulkannya kepada menteri.

Berkaitan dengan hal ini, penulis mencontohkan adanya salah satu fakta hukum yang dapat penulis deskripsikan dalam penelitian ini, yaitu adalah seorang notaris yang diangkat pertama kali, yang bertindak sebagai dan selaku pemegang protokol dari ayahnya yang juga seorang notaris berkedudukan di Kota Denpasar, yang telah berakhir masa jabatannya. Notaris yang baru diangkat tersebut dapat secara otomatis masuk kedalam kategori $\mathrm{C}$ wilayah daerah formasi jabatan Notaris yang menentukan daerah kerja kota Denpasar termasuk didalamnya.

Apabila mengacu kepada Pasal 8 Peraturan Menteri Hukum Dan Hak Asasi Manusia Republik Indonesia Nomor 27 Tahun 2016 tentang Formasi Jabatan Notaris Dan Penentuan Kategori Daerah yang telah diuraikan diatas, yang mana secara tegas telah mengatur terkait dengan perpidahan wilayah jabatan notaris dan pengangkatan pertama kali yang disesuaikan dengan kategorinya, maka seharusnya notaris yang pertama kali diangkat dalam contoh diatas hanya dapat berkedudukan di kategori daerah $\mathrm{D}$, bukan di kategori daerah $\mathrm{C}$.

Sehubungan dengan hal itu, masih terdapat kekaburan norma dengan tidak dijelaskannya mengenai apakah notaris yang baru diangkat dan sekaligus ditunjuk sebagai pemegang protokol dari notaris yang telah berakhir masa kerjanya tersebut dapat dengan otomatis langsung masuk ke wilayah kerja notaris yang telah pensiun tersebut, yang dalam kaitannya dengan ini wilayah kerja dari notaris yang telah berakhir masa jabatannya tersebut adalah wilayah kerja yang menurut Pasal 8 Peraturan Menteri Hukum Dan Hak Asasi Manusia Republik Indonesia Nomor 27 Tahun 2016 tentang Formasi Jabatan Notaris Dan Penentuan Kategori Daerah bukan merupakan kategori daerah untuk notaris yang pertama kali diangkat, ataukah harus tetap mengikuti kategori daerah dalam Pasal 8 tersebut. Lain halnya apabila notaris yang telah berakhir masa jabatannya tersebut berkedudukan di kategori daerah yang telah sesuai dengan kategori daerah yang ditujukan bagi notaris yang pertama kali diangkat sebagaimana diatur dalam Pasal 8, maka notaris pemegang protokol tersebut sudah sesuai dengan aturan mengenai formasi wilayah jabatan notaris.

Undang-undang dan peraturan perundang-undangan yang dibentuk hendaknya haruslah mencerminkan adanya suatu kepastian hukum serta mengatur secara tegas dan spesifik substansi yang menjadi ruang lingkup undang-undang tersebut. Hal ini belum seutuhnya terlihat dalam UUJN dan juga dalam Peraturan Menteri Hukum Dan Hak Asasi Manusia Republik Indonesia Nomor 27 Tahun 2016 tentang Formasi Jabatan Notaris Dan Penentuan Kategori Daerah. 


\subsection{Pengaturan Kedepan Formasi Wilayah Jabatan Notaris Pemegang Protokol Notaris Yang Telah Berakhir Masa Jabatannya}

Seorang notaris merupakan seseorang yang memiliki kewenangan untuk melayani masyarakat khususnya dalan hal mengenai pembuatan akta otentik. Untuk dapat diangkat menjadi notaris, seseorang harus memenuhi persyaratan-persyaratan sebagaimana diatur dalam Pasal 3 Undang-Undang Nomor 2 Tahun 2014 tentang Perubahan atas Undang-Undang Nomor 30 Tahun 2004 tentang Jabatan Notaris.

Wilayah jabatan notaris memiliki peran yang sangat vital dalam pelaksanaan tugasnya dibidang pembuatan akta otentik. Pelanggaran terhadap wilayah jabatan Notaris dapat membawa seorang Notaris keranah pidana/perdata sesuai dengan kasusnya. Pengaturan kedepan formasi wilayah jabatan Notaris dalam pengangkatan pertama kali yang ditunjuk sebagai penerima protokol oleh menteri berdasarkan pada usulan dari Majelis Pengawans Daerah menggunakan teknik interpretasi gramatikal dan sistematis perlu diperjelas lagi teknis dan pertimbangan hukum apa saja yang digunakan oleh Majelis Pengawas Daerah dalam mengusulkan Notaris pemegang protokol yang akan ditunjuk oleh Menteri mengingat masih terdapat adanya kekaburan norma hukum yang terdapat didalam ketentuan Pasal 63 ayat (4) UUJN serta peraturan pelaksananya yakni Pasal 7 dan 8 Peraturan Menteri Hukum Dan Hak Asasi Manusia Republik Indonesia Nomor 27 Tahun 2016 tentang Formasi Jabatan Notaris Dan Penentuan Kategori Daerah.

Notaris yang ditunjuk sebagai penerima protokol tersebut dalam pengangkatan pertama kali hendaknya diberikan prioritas untuk dapat memilih wilayah jabatan yang lebih baik dari sebelumnya dalam menjalankan tugas jabatannya sehari-hari. Sebaiknya aturan mengenai wilayah jabatan notaris penerima protokol dari notaris yang telah berakhir masa jabatannya dicantumkan secara tegas dalam kategori daerah sebagaimana diatur dalam Pasal 8 Peraturan Menteri Hukum Dan Hak Asasi Manusia Republik Indonesia Nomor 27 Tahun 2016 tentang Formasi Jabatan Notaris Dan Penentuan Kategori Daerah.

\section{Kesimpulan}

Kepastian hukum formasi wilayah jabatan notaris dalam hal penunjukan pemegang protokol notaris yang berakhir masa jabatannya berdasarkan pada usulan dari MPD oleh menteri dalam kaitannya dalam pengangkatan pertama kali notaris masih terdapat kekaburan norma sehingga menimbulkan ketidakpastian hukum dalam pengaturannya apakah harus mengikuti kategori daerah yang ditentukan oleh Peraturan Menteri Hukum Dan Hak Asasi Manusia Republik Indonesia Nomor 27 Tahun 2016 tentang Formasi Jabatan Notaris Dan Penentuan Kategori Daerah ataukah ada pengecualian khusus untuk dapat langsung menempati wilayah jabatan sesuai dengan jabatan notaris yang telah berakhir masa jabatannya. Sehingga, pengaturan kedepan mengenai formasi wilayah jabatan notaris dalam pengangkatan pertama kali yang ditunjuk sebagai penerima protokol oleh menteri atas usul Majelis Pengawas Daerah hendaknya lebih dipertegas secara spesifik didalam ketentuan UndangUndang Republik Indonesia Nomor 2 Tahun 2014 tentang Perubahan Atas UndangUndang Nomor 30 Tahun 2004 tentang Jabatan Notaris dan juga di dalam Peraturan 
Menteri Hukum Dan Hak Asasi Manusia Republik Indonesia Nomor 27 Tahun 2016 tentang Formasi Jabatan Notaris Dan Penentuan Kategori Daerah. Terkait dengan kekaburan norma ini disarankan kepada para penegak hukum hendaknya merevisi aturan-aturan tersebut diatas guna memberikan kepastian hukum terkait formasi wilayah jabatan Notaris dalam hal pengangkatan pertama kali dan ditunjuk sebagai penerima protokol Notaris yang berakhir masa jabatannya oleh Menteri atas usul Majelis Pengawas Daerah.

\section{Ucapan Terima Kasih}

Terima kasih yang sebesar-besarnya penulis ucapkan kepada orang tua dan keluarga tercinta serta teman-teman yang tidak bisa penulis sebutkan satu persatu, yang selama ini telah memberi dukungan kepada penulis untuk dapat menyelesaikan penelitian ini. Penulis menyadari bahwa penelitian ini belum dapat dikatakan sempurna, sehingga penulis mengharapkan akan adanya saran dan kritik yang dapat membangun dalam rangka untuk menghasilkan penelitian yang lebih baik lagi. Akhir kata, penulis berharap penelitian ini mampu memberikan manfaat bagi pihak-pihak yang berkepentingan.

\section{Daftar Pustaka / Daftar Referensi}

\section{$\underline{\text { Buku }}$}

Ibrahim, Jhony. (2005). Teori \& Metodelogi Penelitian Hukum Normatif. Surabaya: Bayu Media.

Soekanto, Soerjono dan Mahmudji, Sri. (2003). Penelitian Hukum Normatif, Suatu Tinjauan Singkat. Jakarta: Raja Grafindo Persada.

Tan Thong Kie. (2011). Studi Notariat dan Serba-Serbi Praktek Notaris. Cetakan Kedua. Jakarta: PT. Ichtiar Baru van Hoeve.

\section{Jurnal}

Andriana, R., \& Chalim, M. A. (2017). AKIBAT HUKUM BAGI NOTARIS YANG MENOLAK PROTOKOL DARI NOTARIS LAIN. Jurnal Akta, 4(2), 223-230. h.

Astiriani, R. G. (2015). Analisis Yuridis terhadap Putusan Mahkamah Konstitusi Nomor 5/puu-xii/2014 Terkait Ketentuan Formasi Jabatan Notaris dalam Uujn sebagai Syarat Pengangkatan Notaris. Kumpulan Jurnal Mahasiswa Fakultas Hukum.

Erwinsyahbana, T., \& Melinda, M. (2018). Kewenangan dan Tanggung Jawab Notaris Pengganti setelah Pelaksanaan Tugas dan Jabatan Berakhir. Lentera Hukum, 5(2), 305-321. 
Purwanto, A. (2018). PERTANGGUNGJAWABAN AHLI WARIS NOTARIS DAN MPD TERHADAP PROTOKOL NOTARIS YANG MENINGGAL DUNIA. Jurnal Repertorium, 5(2).

Witasari, A. (2018). Mpd Bukan Advokat Para Notaris Berdasarkan Undang-undang No. 30 Tahun 2004 Tentang Jabatan Notaris. Jurnal Hukum, 28(2), 882-899.

\section{Peraturan Perundang-Undangan}

Undang-Undang Nomor 2 Tahun 2014 tentang Perubahan atas Undang-Undang Nomor 30 Tahun 2004 tentang Jabatan Notaris

Peraturan Menteri Hukum Dan Hak Asasi Manusia Republik Indonesia Nomor 27 Tahun 2016 tentang Formasi Jabatan Notaris Dan Penentuan Kategori Daerah 